\title{
$\begin{array}{ll}2 & \text { Smithsonian Institution } \\ \text { Scholarly Press }\end{array}$
}

SMITHSONIAN CONTRIBUTIONS TO ZOOLOGY • NUMBER 645
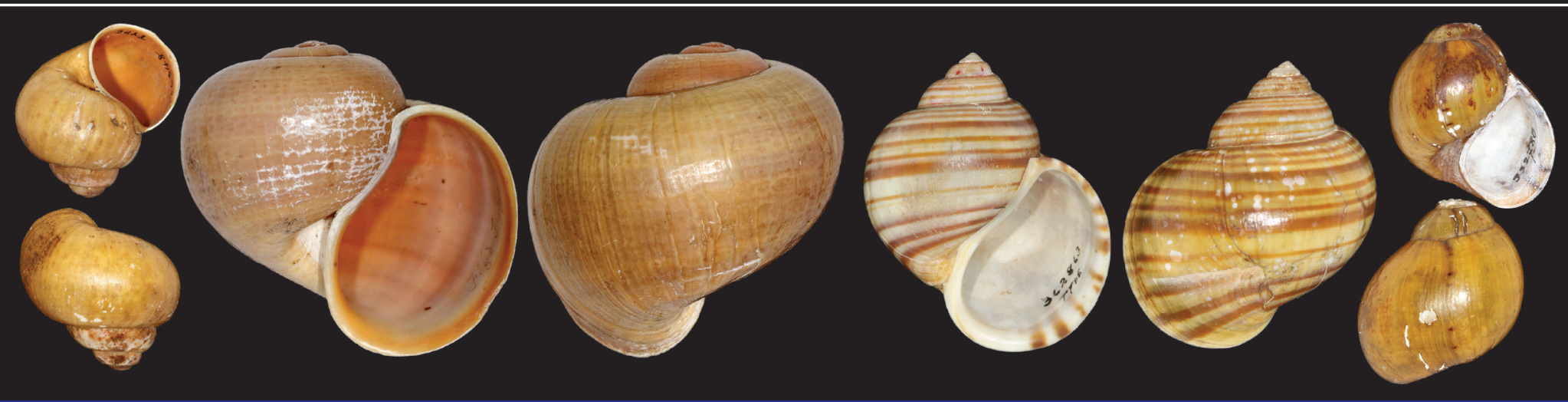

Types of Ampullariidae
(Mollusca: Gastropoda)

in the National Museum

\section{of Natural History,}

Smithsonian Institution,

$$
\begin{gathered}
\text { with Lectotype } \\
\text { Designations }
\end{gathered}
$$

Robert H. Cowie, Kenneth A. Hayes,

and Ellen E. Strong 


\title{
SERIES PUBLICATIONS OF THE SMITHSONIAN INSTITUTION
}

Emphasis upon publication as a means of "diffusing knowledge" was expressed by the first Secretary of the Smithsonian. In his formal plan for the Institution, Joseph Henry outlined a program that included the following statement: "It is proposed to publish a series of reports, giving an account of the new discoveries in science, and of the changes made from year to year in all branches of knowledge." This theme of basic research has been adhered to through the years by thousands of titles issued in series publications under the Smithsonian imprint, commencing with Smithsonian Contributions to Knowledge in 1848 and continuing with the following active series:

\author{
Smithsonian Contributions to Anthropology \\ Smithsonian Contributions to Botany \\ Smithsonian Contributions to History and Technology \\ Smithsonian Contributions to the Marine Sciences \\ Smithsonian Contributions to Museum Conservation \\ Smithsonian Contributions to Paleobiology \\ Smithsonian Contributions to Zoology
}

In these series, the Institution publishes small papers and full-scale monographs that report on the research and collections of its various museums and bureaus. The Smithsonian Contributions Series are distributed via mailing lists to libraries, universities, and similar institutions throughout the world.

Manuscripts intended for publication in the Contributions Series undergo substantive peer review and evaluation by SISP's Editorial Board, as well as evaluation by SISP for compliance with manuscript preparation guidelines (available on SISP's “Author Resources” page at www.scholarlypress.si.edu). For open access, fully searchable PDFs of volumes in the Smithsonian Contributions Series, visit Open SI (http://opensi.si.edu). 
Types of Ampullariidae (Mollusca: Gastropoda) in the National Museum of Natural History, Smithsonian Institution,

$$
\begin{gathered}
\text { with Lectotype } \\
\text { Designations }
\end{gathered}
$$

Robert H. Cowie, Kenneth A. Hayes,

and Ellen E. Strong

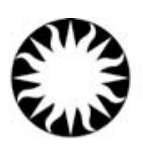

Smithsonian Institution

Scholarly Press

WASHINGTON, D.C. 


\begin{abstract}
Cowie, Robert H., Kenneth A. Hayes, and Ellen E. Strong. Types of Ampullariidae (Mollusca: Gastropoda) in the National Museum of Natural History, Smithsonian Institution, with Lectotype Designations. Smithsonian Contributions to Zoology, number 645, iv +13 pages, 1 figure, 2015.-The caenogastropod family Ampullariidae Gray, 1824, is a family of freshwater snails predominantly distributed in humid tropical and subtropical habitats in Africa, South and Central America, and Asia. The family includes the largest of all freshwater snails and frequently constitutes a major portion of the native freshwater malacofauna of these regions. Ampullariid taxonomy is confused primarily because most species were described on the basis of only shell morphology, which is highly variable within species yet relatively conservative among species within the family. The need for rigorous taxonomic treatment of the group is acute, and a starting point for such research is a comprehensive study of type material. With type or possible type material of 20 nominal species-group taxa of Ampullariidae, belonging to the genera Afropomus Pilsbry and Bequaert, 1927 (1 taxon, from Africa), Felipponea Dall, 1919 (2, South America), Forbesopomus Bequaert and Clench, 1937 (1, Asia), Lanistes Montfort, 1810 (2, Africa), Pila Röding, 1798 (2, Asia), and Pomacea Perry, 1810 (11, South, Central, and North America), as well as 1 incertae sedis taxon in Pila or Pomacea, the U.S. National Museum of Natural History, Smithsonian Institution, has significant holdings, for which this annotated catalogue is provided. To stabilize the nomenclature, lectotypes are designated for eight species-group taxa. No new synonyms are proposed, other than as a result of the provision of a replacement name for elongata Dall, 1921, non d'Orbigny, 1842, nec Rochebrune and Germain, 1904. Accounts are arranged alphabetically by original published species-group name. Information in each account includes original name and combination, citation to the original description, current taxonomic status, type material held by the U.S. National Museum (holotypes, paratypes, syntypes, lectotypes, paralectotypes, and one neotype) with catalogue number(s) and number of specimens in each catalogue lot, type locality, and other remarks or additional information as appropriate. All name-bearing types are illustrated.
\end{abstract}

Cover images: Apertural and abapertural views of ampullariid shells of (left to right) Paludina sinistrosa, Ampullaria pinei, A. superba, and A. (Felipponea) neritiniformis (from Figure 1J, H, K, F, respectively, herein).

\author{
Published by SMITHSONIAN INSTITUTION SCHOLARLY PRESS \\ P.O. Box 37012, MRC 957, Washington, D.C. 20013-7012 \\ www.scholarlypress.si.edu
}

Compilation copyright (C) 2015 Smithsonian Institution

The rights to all text and images in this publication, including cover and interior designs, are owned either by the Smithsonian Institution, by contributing authors, or by third parties. Fair use of materials is permitted for personal, educational, or noncommercial purposes. Users must cite author and source of content, must not alter or modify copyrighted content, and must comply with all other terms or restrictions that may be applicable. Users are responsible for securing permission from a rights holder for any other use.

\title{
Library of Congress Cataloging-in-Publication Data
}

National Museum of Natural History (U.S.).

Types of Ampullariidae (Mollusca:Gastropoda) in the National Museum of Natural History, Smithsonian Institution, with lectotype designations / Robert H. Cowie, Kenneth A. Hayes, and Ellen E. Strong.

pages $\mathrm{cm}$. - (Smithsonian contributions to zoology ; number 645)

Includes bibliographical references and index.

1. Ampullariidae-Type specimens—Catalogs and collections-Washington (D.C.) 2. National Museum of Natural History (U.S.)—Catalogs. I. Cowie, Robert H., 1954- II. Hayes, Kenneth A. III. Strong, Ellen E. IV. Title.

QL430.5.A57N38 2015

594'.3209753—dc23

2015024160

ISSN: 1943-6696 (online); 0081-0282 (print)

Publication date (online): 25 September 2015

ZooBank registration: 15 September 2015 (LSID: urn:lsid:zoobank.org:pub:DB1AF5F1-0629-4839-BA1D-5848F6AB463E)

( The paper used in this publication meets the minimum requirements of the American National Standard for Permanence of Paper for Printed Library Materials Z39.48-1992. 


\section{Contents}

INTRODUCTION

Approach and Format of Accounts 2

Abbreviations and Acronyms $\quad 2$

Acknowledgments 2

CATALOGUE OF TYPE MATERIAL OF AMPULLARIIDAE GRAY, 1824

atalanta Bequaert and Clench, 1937

aurostoma Lea, 1856

balanoidea Gould, 1850

canaliculata Lamarck, 1822

columellaris Gould, $1848+4$

dalli Cowie, Hayes, and Strong, nomen novum 4

elongata Dall, 1921

gracilis Lea, $1856 \quad 6$

meridaensis Pain, $1950 \quad 6$

miamiensis Pilsbry, $1899 \quad 6$

neavei Melvill and Standen, $1907 \quad 6$

neritiniformis Dall, $1919 \quad 6$

oligista Pilsbry and Olsson, $1953 \quad 6$

palmeri Marshall, $1930 \quad 7$

pinei Dall, 1898

sanjosensis Morrison, $1946 \quad 7$

sinistrosa Lea, $1838 \quad 7$

$\begin{array}{ll}\text { superba Marshall, } 1926 & 7\end{array}$

tubaeformis Lea, $1856 \quad 8$

$\begin{array}{ll}\text { turbinis Lea, } 1856 & 8\end{array}$

zeteki Morrison, $1946 \quad 8$

MATERIAL PREVIOUSLY CONSIDERED AS TYPES 9

zischkai Blume and Pain, 1952

REFERENCES 11 



\section{Types of Ampullariidae (Mollusca: Gastropoda) in the National Museum of Natural History, Smithsonian Institution, with Lectotype Designations}

Robert H. Cowie, ${ }^{1}$ Kenneth A. Hayes, ${ }^{2,3^{*}}$ and Ellen E. Strong ${ }^{3}$

${ }^{1}$ Pacific Biosciences Research Center, University of Hawaii, 3050 Maile Way, Gilmore 408, Honolulu, Hawaii, 96822, USA.

${ }^{2}$ Department of Biology, Howard University, 415 College St. NW, Washington, D.C., 20059, USA.

${ }^{3}$ National Museum of Natural History, Smithsonian Institution, P.O. Box 37012, MRC 163, Washington, D.C., 20013, USA.

*Correspondence: kenneth.hayes@howard.edu Manuscript received 27 February 2015; accepted 14 May 2015.

\section{INTRODUCTION}

The caenogastropod family Ampullariidae Gray, 1824 (junior synonym Pilidae Preston, 1915-Cowie, 1997; ICZN, 1999a; Bouchet and Rocroi, 2005), within the superfamily Ampullarioidea, is placed in the informal group Architaenioglossa, which also includes the Cyclophoroidea Gray, 1847, and Viviparoidea Gray, 1847 (Bouchet and Rocroi, 2005). The Campaniloidea Douvillé, 1904, is closely related, but the relationships among the four superfamilies remain unresolved (Ponder and Lindberg, 1997; McArthur and Harasewych, 2003; Strong, 2003; Simone, 2004; Colgan et al., 2007; Jørgensen et al., 2008; Ponder et al., 2008; Hayes et al., 2009).

Ampullariidae are freshwater snails predominantly distributed in humid tropical and subtropical habitats in Africa, South and Central America, and Asia (Hayes et al., 2015). They include the largest of all freshwater snails (Pomacea maculata Perry, 1810, can attain greater than $165 \mathrm{~mm}$ in adult shell height; Hayes et al., 2012) and frequently constitute a major portion of the native freshwater mollusc faunas of these regions. Of 14 Neotropical freshwater snail families, Ampullariidae constitute $20 \%$ of the Recent species (Strong et al., 2008).

Within the Ampullariidae, nine extant genera have been recognized in modern treatments (Cowie, 2015; Hayes et al., 2015). The great majority of the species are referred to just three genera: Lanistes Montfort, 1810 (Africa, including Madagascar), with 43 recent species currently considered valid; Pila Röding, 1798 (Ampullaria Lamarck, 1799, and Ampullarius Montfort, 1810, are junior synonyms-Cowie 1997; ICZN 1999a) (Africa and Asia), with 29 species; and Pomacea Perry, 1810 (South, Central, and North America) with 97 species (Hayes et al., 2015). The remaining six genera contain only one or a few species: Afropomus Pilsbry and Bequaert, 1927, and Saulea Gray, 1868 (1 species each) are African; Asolene d'Orbigny, 1838 (8 species), Felipponea Dall, 1919 (3 species), and Marisa Gray, 1824 (2 species) are South American; and Forbesopomus Bequaert and Clench, 1937 (1 species) is Asian (Hayes et al., 2015).

Taxonomy within the family is confused and complicated (e.g., Cowie et al., 2006), and delimitation of the genera and assignment of species to genera is in some cases uncertain 
or incorrect and in need of revision (Hayes et al., 2009, 2015). These problems are primarily because most species were described only on the basis of shell morphology, which is highly variable within species yet relatively conservative among species, such that the variable shell morphology of many species appears to overlap that of others. In the light of this confusion and the need for rigorous taxonomic research, it is crucial to study type material. Ascertaining the location of type material and its correct status is the necessary first step.

By far the largest museum collection of ampullariid type material is in the Natural History Museum, London. Other major collections, in roughly decreasing order of total numbers of lots of ampullariid types, include the Muséum national d'Histoire naturelle, Paris (its ampullariid types catalogued by Cowie and Héros, 2012); the Museum of Comparative Zoology, Harvard University; the Museum für Naturkunde, Berlin (its ampullariid types catalogued by Köhler and Glaubrecht, 2006); the Museo Nacional de Historia Natural, Santiago, Chile (its ampullariid type material dominated by the collections of Philippi and noted by Cowie, 2015, and by A. R. Kabat [Harvard University, Museum of Comparative Zoology] and E. V. Coan [Santa Barbara Museum of Natural History, Invertebrate Zoology], unpublished); the Academy of Natural Sciences of Drexel University, Philadelphia (its ampullariid types catalogued by Cowie et al., submitted); the National Museum of Wales, Cardiff; and the Forschungsinstitut und Naturmuseum Senckenberg, Frankfurt-am-Main. The ampullariid type material of the Zoologische Staatssammlung München is dominated by the South American collections of Spix, whose material was catalogued by Fechter (1983) and discussed briefly by Cowie et al. (2004). Many other museum collections, including the U.S. National Museum (USNM) within the National Museum of Natural History, Smithsonian Institution (NMNH), Washington, D.C., house additional type material (Cowie and Thiengo, 2003; Cowie, 2015). The purpose of the present catalogue is to document the type material of Ampullariidae housed in the USNM, following Recommendation 72F.4 of the International Code of Zoological Nomenclature (ICZN, 1999b).

\section{Approach and Format of Accounts}

In this catalogue, taxa are arranged alphabetically by species-group name. The name and original combination are given following the name, verbatim as in the original description, and are followed by the bibliographic details of the original description. Bibliographic details of subsequent publications bearing directly on the original description are provided, as necessary for clarification, in square brackets. The type locality is as given in the original description, with original orthography within quotation marks, although when needed, changes for capitalization are in square brackets. Also in square brackets is additional type locality information when available.

Only the following type specimens are included in this catalogue: holotypes, syntypes, lectotypes, and one neotype, as well as paratypes and paralectotypes. Other specimens are only discussed as necessary for clarification, including non-type material of one species (Pomacea zischkai Blume and Pain, 1952). Catalogue numbers are those of lots in the mollusc collection in the USNM. The number of specimens in each lot is indicated. The current taxonomic status includes generic and subgeneric placement (the latter only if not the nominotypical subgenus), whether a valid taxon, and if not, the appropriate synonymy. Unless otherwise stated, generic placements and synonymies for New World taxa follow Cowie and Thiengo (2003) and for Old World taxa (Africa and Asia) follow Cowie (2015).

All interpretations follow the fourth edition of the International Code of Zoological Nomenclature (ICZN 1999b).

\section{AbBreviations AND ACrONYMS}

\begin{tabular}{|c|c|}
\hline ANSP & $\begin{array}{l}\text { Academy of Natural Sciences of Drexel Univer- } \\
\text { sity, Philadelphia, Pennsylvania, USA }\end{array}$ \\
\hline Code & $\begin{array}{l}\text { International Code of Zoological Nomenclature } \\
\text { (ICZN, 1999b) }\end{array}$ \\
\hline FMNH & Field Museum, Chicago, Illinois, USA \\
\hline MCZ & $\begin{array}{l}\text { Museum of Comparative Zoology, Harvard Uni- } \\
\text { versity, Cambridge, Massachusetts, USA }\end{array}$ \\
\hline MMUE & $\begin{array}{l}\text { The Manchester Museum, University of Man- } \\
\text { chester, Manchester, UK }\end{array}$ \\
\hline NMNH & $\begin{array}{l}\text { National Museum of Natural History, Smithson- } \\
\text { ian Institution, Washington, D.C., USA }\end{array}$ \\
\hline $\begin{array}{l}\text { NMW } \\
\text { n. syn. }\end{array}$ & $\begin{array}{l}\text { National Museum of Wales, Cardiff, UK } \\
\text { new synonymy }\end{array}$ \\
\hline USNM & $\begin{array}{l}\text { U.S. National Museum (within the NMNH), } \\
\text { Washington D.C., USA }\end{array}$ \\
\hline ZSM & Zoologische Staatssammlung München, Germany \\
\hline
\end{tabular}

\section{ACKNOWLEDGMENTS}

We thank Neal Evenhuis for discussion of our interpretations of the Code and Norine Yeung for assistance with photography and help locating specimens in the collection. Funding was provided in part by National Science Foundation grant DEB-0949061. 


\section{Catalogue of Type Material of Ampullariidae Gray, 1824}

atalanta Bequaert and Clench, 1937

Forbesopomus atalanta Bequaert and Clench, 1937:54, pl. 2, figs. 1-7.

Current Taxonomic Status: Forbesopomus atalanta Bequaert and Clench, 1937; valid species (Cowie, 2015:10).

Type Material: Paratype USNM 530146 (1 specimen).

Type Locality: "Lake Lanao, Misamis, Mindanao, Philippine Islands."

Remarks: Only known from the type locality and the type series. Holotype, by original designation, figured, and with dimensions given (Bequaert and Clench, 1937:55, pl. 2, figs. 1-7), in the MCZ; additional paratypes in the MCZ and the NMW (Bequaert and Clench, 1937:55; Cowie, 2015:10). The gender of Pomus in Latin, and hence of Forbesopomus, is feminine.

aurostoma Lea, 1856

FIGURE $1 \mathrm{~A}$

Ampullaria aurostoma Lea, 1856:110.

Current taxonomic status: Pomacea aurostoma (Lea, 1856); valid species (Cowie and Thiengo, 2003:57).

Type Material: Lectotype USNM 106299 (1 specimen), here designated; paralectotypes USNM 1270616 (formerly 106299X; 3 specimens); possible paralectotypes USNM 106273 (11 specimens).

Type Locality: "Carthagena” [Colombia].

Remarks: No holotype was designated and there are multiple type specimens, although the specimen (USNM 106299) figured subsequent to the original description by Lea (1866, pl. 22, fig. 4) is labeled "holotype"; based on the banding pattern of the shell, it is the one illustrated, and it bears the corresponding figure number inked on the body whorl. We therefore designate the shell in USNM 106299 as the lectotype to stabilize the name. The paralectotypes (USNM 1270616) were not noted by Cowie and Thiengo (2003:57), who listed the possible paralectotypes in USNM 106273 (labeled "unconfirmed type") as syntypes. A comment in the original handwritten ledger indicates that the latter lot comprises "fossil shells found $10 \mathrm{ft}$. below surface." 


\section{balanoidea Gould, 1850}

Ampullaria balanoidea Gould, 1850:196.

Current taxonomic status: Afropomus balanoidea (Gould, 1850); valid species (Cowie, 2015:10).

Type Material: Paralectotype USNM 611247 (1 specimen).

Type Locality: "Grand Cape Mount, Liberia."

Remarks: No holotype was designated, nor has it been determined that Gould based his description on only a single specimen. The lectotype (MCZ 169054) was designated by Johnson (1964:45). The gender of Pomus in Latin, and hence of Afropomus, is feminine.

\section{canaliculata Lamarck, 1822}

\section{FIGURE 1B}

Ampullaria canaliculata Lamarck, 1822:178.

Current taxonomic status: Pomacea canaliculata (Lamarck, 1822); valid species (Cowie and Thiengo, 2003:58; Hayes et al., 2012:737).

Type Material: Neotype USNM 1185844 (1 specimen, in ethanol).

Type Locality: "Palermo, Buenos Aires, Argentina."

Remarks: Hayes et al. (2012:741) considered the original type material to be lost and therefore designated a neotype. The original type locality was "les rivières de la Guadeloupe," which may have been Lago Guadalupe (also referred to as Laguna Guadalupe, but now known as Laguna Setúbal) in Argentina and not the island of Guadeloupe, although this is conjecture (Pain, 1946:58; Hylton Scott, 1958:300; Thiengo et al., 1993:68; Cazzaniga, 2002:74; Cowie and Thiengo, 2003:58). However, in designating a neotype the type locality was fixed as above.

\section{columellaris Gould, 1848}

FIGURE 1C

Ampullaria columellaris Gould, 1848:74.

Current taxonomic status: Pomacea columellaris (Gould, 1848); valid species (Cowie and Thiengo, 2003:60).

Type Material: Holotype USNM 5547, by monotypy.

Type Locality: "Province of Maynas, Peru."

Remarks: No holotype was designated in the original publication. However, Gould (1852:128) implied that the original description was based on a single specimen ("the shell"), which he illustrated (Gould, 1852: pl. 9, figs. 147, 147a). The specimen in USNM 5547 is the shell illustrated, based on both the shell banding pattern and the configuration of repair scars, especially the prominent scar on the early part of the body whorl. We accept this specimen as the holotype by monotypy (Code, Article 73.1.2). The reference by Johnson (1964:57) to this specimen as the "figured holotype" was taken incorrectly by Cowie and Thiengo (2003:60) as fixation of a lectotype, citing Article 74.6 and Recommendation $73 \mathrm{~F}$ of the Code.

\section{dalli Cowie, Hayes, and Strong, nomen novum}

\author{
FIGURE 1D
}

Felipponea dalli Cowie, Hayes, and Strong, nomen novum pro elongata Dall, 1821 (see also elongata Dall).

Current taxonomic status: Felipponea dalli Cowie, Hayes, and Strong, 2015; valid species (Cowie and Thiengo, 2003:49, as "elongata Dall”).

Type Material: Lectotype USNM 333024 (1 specimen), here designated.

Type Locality: "Uruguay River, Dept. of Paysandú" (Dall, 1921:133, as "elongata").

Remarks: The name elongata Dall is a junior primary homonym of elongata d'Orbigny and of elongata Rochebrune and Germain (Cowie and Thiengo, 2003:49; Cowie, 2015:35). There is no available and potentially valid synonym of elongata Dall, so a new substitute name, dalli Cowie, Hayes, and Strong, is here provided (Code, Article 60.3). The name honors William Healey Dall, American naturalist, malacologist, honorary curator at the NMNH, and the author of elongata Dall. No holotype of elongata Dall was designated, nor has it been determined for certain that Dall based his description on only a single specimen, although he provided dimensions of only one shell and a catalogue number (USNM 333024) of a lot, labeled "holotype," that contains only one shell. On the basis of the label, Cowie and Thiengo (2003:49) listed this shell as the holotype; their listing did not constitute designation of the specimen as a lectotype. We here avoid assumption of a holotype (Code, Recommendation 73F) and formally designate the shell in USNM 333024 as the lectotype to stabilize the name. This specimen is automatically also designated as the lectotype of elongata Dall (Code, Article 72.7).

\section{elongata Dall, 1921}

Ampullaria (Felipponea) elongata Dall, 1921:133.

Current nomenclatural and taxonomic status: Junior primary homonym of Ampullaria fasciata variété elongata d'Orbigny, 1842, and of Ampullaria kordofana variété elongata Rochebrune and Germain, 1904, replaced here by dalli Cowie, Hayes, and Strong (see dalli, above); objective synonym of dalli Cowie, Hayes, and Strong (Code, Article 72.7); n. syn.

Type Material: Lectotype USNM 333024 (1 specimen), here designated. Type Locality: “Uruguay River, Dept. of Paysandú” (Dall, 1921:133).

Remarks: The name-bearing type (lectotype) of both elongata Dall and dalli Cowie, Hayes, and Strong is the same specimen (Code, Article 72.7). Ampullaria elongata Bennett, 1831, is a nomen nudum, so unavailable, and therefore does not enter homonymy; it was noted by Cowie and Thiengo (2003:81) as not being an ampullariid. 


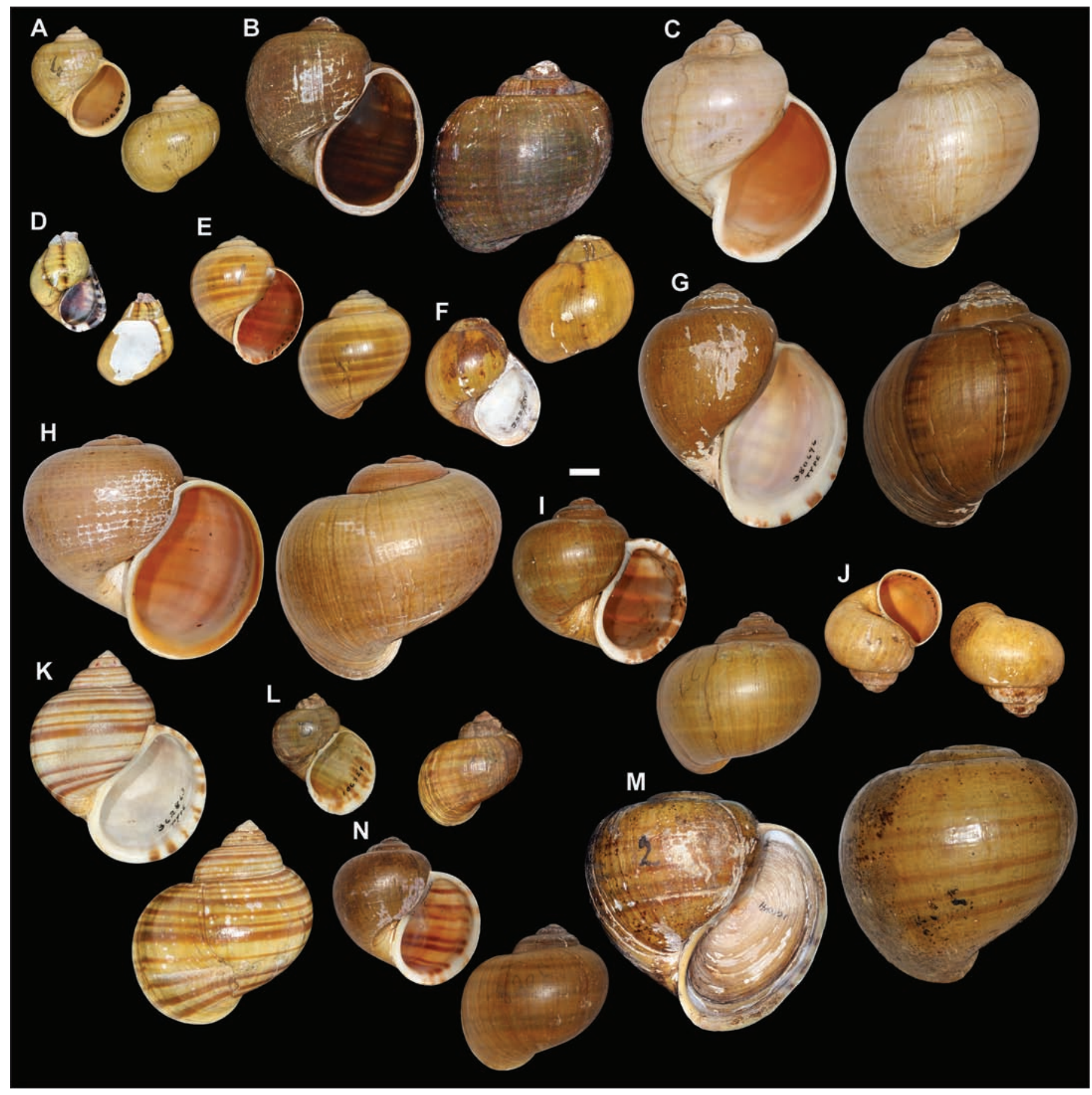

FIGURE 1. Shells (apertural and abapertural views) of selected Ampullariidae species discussed herein. Dimensions given for each are shell height (length) in millimeters measured with digital calipers parallel to the columella. (A) Ampullaria aurostoma Lea, 1856, lectotype USNM 106299, 28.9 mm; (B) A. canaliculata Lamarck, 1822, neotype USNM 1185844, $54.1 \mathrm{~mm}$; (C) A. columellaris Gould, 1848, holotype USNM 5547, 63.8 mm; (D) A. (Felipponea) dalli Cowie, Hayes, and Strong, nomen novum pro Ampullaria (Felipponea) elongata Dall, 1921, lectotype USNM 333024, 27.6 mm; (E) A. gracilis Lea, 1856, lectotype USNM 106323, 35.4 mm; (F) A. (Felipponea) neritiniformis Dall, 1919, lectotype USNM 332780, 33.1 mm; (G) A. palmeri Marshall, 1930, holotype USNM 380696, 66.2 mm; (H) A. pinei Dall, 1898, lectotype USNM 152699, 59.8 mm; (I) Pomacea cumingii sanjosensis Morrison, 1946, holotype USNM 542136, 44.4 mm; (J) Paludina sinistrosa Lea, 1838, lectotype USNM 106348, 32.0 mm; (K) A. superba Marshall, 1926, holotype USNM 362863, 52.0 mm; (L) A. tubaeformis Lea, 1856, holotype USNM 106329, 33.1 mm; (M) A. turbinis Lea, 1856, lectotype USNM 106341, 61.9 mm; and (N) Pomacea zeteki Morrison, 1946, holotype USNM 542137, $40.5 \mathrm{~mm}$. Scale bar $=1 \mathrm{~cm}$. 


\section{gracilis Lea, 1856}

\author{
FIGURE 1E
}

Ampullaria gracilis Lea, 1856:110.

Current taxonomic status: Pila gracilis (Lea, 1856); valid species (Cowie, 2015:37).

Type Material: Lectotype USNM 106323 (1 specimen), here designated; paralectotype USNM 1272906 (formerly 106323a) (1 specimen).

Type Locality: "Siam” [Thailand].

Remarks: No holotype was designated and the description was based on two specimens (Lea, 1866:113). The specimen (USNM 106323), figured subsequent to the original description by Lea (1866, pl. 22, fig. 1), is labeled "holotype"; based on the banding pattern of the shell, it is the one illustrated, and it bears the corresponding figure number inked on the body whorl. We here designate this specimen (USNM 106323) as the lectotype to stabilize the name.

\section{meridaensis Pain, 1950}

Pomacea (Limnopomus) meridaensis Pain, 1950:109.

Current taxonomic status: Synonym of Pomacea camena Pain, 1949 (Pain, 1957:175; Cowie and Thiengo, 2003:69).

Type Material: Paratypes USNM 595032 (2 specimens).

Type Locality: "Merida, Venezuela."

Remarks: The holotype, designated by Pain (1950:110), is the specimen figured by Alderson (1925: pl. 11, fig. 7), the whereabouts of which is not known to us. Additional paratypes are in various museum collections (Cowie and Thiengo, 2003:69); one of them may in fact be the holotype.

\section{miamiensis Pilsbry, 1899}

Ampullaria miamiensis Pilsbry, 1899:365 [1927:252, pl. 22, figs. 5 (lectotype), 6, 7].

Current taxonomic status: Synonym of Pomacea paludosa (Say, 1829).

Type Material: Possible paralectotypes USNM 160193 (2 specimens).

Type Locality: "[I]n a creek flowing from the Everglades near Miami, Dade County, in southeastern Florida.”

Remarks: Use of the term "type" by Pilsbry (1927:253, pl. 22, figs. 5-7) for a specimen in the ANSP constitutes a valid lectotype designation according to the Code (Article 74.5); see also Baker (1964:168) and Cowie and Thiengo (2003:69). Additional paralectotypes are in various museum collections (Cowie and Thiengo, 2003:69). Treated by Clench and Turner (1956:122) as a "local population" of Pomacea paludosa (Say, 1829), which we here consider to constitute synonymy, although Cowie and Thiengo (2003:69) retained it noncommittally as an infraspecific taxon of that species. Cowie and Thiengo (2003:69) erroneously noted only one specimen in USNM 160193 neavei Melvill and Standen, 1907

Lanistes neavei Melvill and Standen, 1907:6, unnumbered pl., fig. 1.

Current taxonomic status: Lanistes neavei Melvill and Standen, 1907; valid species (Cowie, 2015:21).

Type Material: Syntype USNM 708877 (1 specimen).

Type Locality: "Kapopo" [southwest of Ndola, Zambia (Neave, 1907: unnumbered pl.)].

Remarks: USNM 708877 is labeled "paralectotype," but no lectotype appears to have been designated. Other syntypes are in various museums (Cowie, 2015:21), and the specimen figured in the original publication (MMUE EE.7815) is the best candidate for future designation as the lectotype (Code, Recommendation 74B).

\section{neritiniformis Dall, 1919}

\author{
FIGURE 1F
}

Ampullaria (Felipponea) neritiniformis Dall, 1919:10.

Current taxonomic status: Felipponea neritiniformis (Dall, 1919); valid species (Cowie and Thiengo, 2003:49).

Type Material: Lectotype USNM 332780, here designated; paralectotypes USNM 1270739 (formerly 332780X; 3 specimens).

Type Locality: "Rio Uruguay, Department of Paysandu” [Uruguay].

Remarks: The original description was based on more than one specimen and Dall did not designate a holotype, although he provided dimensions of only one shell and a single catalogue number (USNM 332780) of a lot (labeled "holotype") that contains only one shell. Cowie and Thiengo (2003:49) listed this shell as the holotype, based on the label; their listing did not constitute fixation of the specimen as a lectotype. We designate the shell in USNM 332780 as the lectotype to stabilize the name. According to the handwritten ledger there was also a radula preparation derived from the original lot, but it could not be located.

\section{oligista Pilsbry and Olsson, 1953}

Pomacea (Effusa) oligista Pilsbry and Olsson, 1953:98, pl. 6, fig. 6.

Current taxonomic status: Incertae sedis in Pomacea (Effusa).

Type Material: Paratypes USNM 605847 (3 specimens).

Type Locality: "[O]n the road ... from Cartagena to Barranquilla ... a freshwater lake known as the Cienaga de Luruaco" [Colombia].

Remarks: The holotype (by original designation) and additional paratypes are in ANSP (Baker 1964:168; Cowie and Thiengo, 2003:55). Synonymized by Pain (1956:76-77) with Pomacea (Effusa) planorbula (Philippi, 1852), which he treated as a valid species but which Cowie and Thiengo (2003:55) retained as only an infraspecific taxon following Baker (1930:12, 24) and Pilsbry (1933:72), the latter considering Ampullaria planorbula Philippi, 1852 "to be the young stage of some variety of P. (Effusa) glauca (L.).” Pending further research, we retain oligista Pilsbry and Olsson, 1953, as an infraspecific taxon of undetermined status and specific affinity. 


\section{palmeri Marshall, 1930}

\author{
FIGURE 1G
}

Ampullaria palmeri Marshall, 1930:4, pl. 1, figs. 5, 8 .

Current taxonomic status: Pomacea palmeri (Marshall, 1930); valid species (Cowie and Thiengo, 2003:71).

Type Material: Holotype USNM 380696, by original designation; paratypes USNM 380697 (4 specimens).

Type Locality: "[S]mall stream in a dense jungle, 13 kilometers south of Puerto Santos, Province of Santander del Norte, Republic of Colombia.”

Remarks: The USNM catalogue number and dimensions of the holotype were given by Marshall (1930:5), who also noted three paratypes as USNM 380697 (in fact there are four specimens in this lot). The lot (USNM 380698; 133 specimens) described by Marshall (1930:5) as "embryonic shells" is not type material, as its listing separately from the "type" and "paratypes" expressly excludes it from the type series (Code, Article 72.4.6).

\section{pinei Dall, 1898}

\section{FIGURE $1 \mathrm{H}$}

Ampullaria pinei Dall, 1898:75.

Current taxonomic status: Synonym of Pomacea paludosa (Say, 1829) (Clench and Turner, 1956:120; Cowie and Thiengo, 2003:71).

Type Material: Lectotype USNM 152699 (1 specimen), here designated; paralectotypes USNM 1270740 (formerly 152699X; 11 specimens).

Type Locality: "Homosassa River, Florida."

Remarks: A label, noted by Cowie and Thiengo (2003:72), indicated that USNM 152699 was the figured “type,” although Dall (1898:75-76) did not designate or figure a type, and there are multiple type specimens. We designate the shell in USNM 152699 as the lectotype to stabilize the name.

\section{sanjosensis Morrison, 1946}

FIGURE 1I

Pomacea cumingii sanjosensis Morrison, 1946:6, pl. 1, fig. 1.

Current taxonomic status: Pomacea cumingii sanjosensis Morrison, 1946; valid subspecies (Cowie and Thiengo, 2003:74).

Type Material: Holotype USNM 542136, by original designation; paratypes USNM 588458 (19 specimens), USNM 588459 (10 specimens, 4 operculae), USNM 588511 (3 specimens), USNM 598924 (25 specimens), USNM 599037 (12 specimens).

Type Locality: "[T]hree small streams (not of contiguous drainage) on the west side of San José island" [Panama; the catalogue ledger entry associated with USNM 599037 indicates “about $1 / 4$ mi. from mouth” but does not specify which stream.]

Remarks: Morrison (1946:7) gave the USNM catalogue number and dimensions of the "type"; although he also gave dimensions of the "largest of many specimens seen" (according to the ledger, the "largest specimens measured" were from USNM 588511) and of the "smallest adult shell," he was not more explicit in identifying the paratypes. There are 10 specimens in USNM 588459 but only 9 recorded in the ledger, although the lot includes several hatchlings, one of which could have been easily overlooked. The catalogue ledger notes 27 specimens in USNM 598924; the two missing specimens were not located in adjacent lots.

\section{sinistrosa Lea, 1838}

FIGURE 1J

Paludina sinistrosa Lea, 1838: 90, pl. 23, fig. 78.

Current taxonomic status: Lanistes sinistrosus (Lea, 1838); valid species (Cowie, 2015:26).

Type Material: Lectotype USNM 106348 (1 specimen), here designated. Type Locality: "East Indies."

Remarks: No holotype was designated, although USNM 106348 was labeled "holotype." Lea obtained from a Miss Hodges "one of the two specimens which were in her fine cabinet" and noted both his own and her cabinet as repositories. Thus, the description may or may not have been based on just the one specimen actually given to him. We avoid assumption of a holotype (Code, Recommendation 73F) and designate USNM 106348 as the lectotype to stabilize the name. This rather nondescript shell has the catalogue number and "type" written on the inside of its aperture and is consistent with the original figure of Lea (1838:fig. 78), but it bears no distinguishing features or figure number inked on the body whorl to conclusively deem it as such. Pilsbry and Bequaert (1927:195) placed it in Lanistes, which is African only, and considered the original locality erroneous, having seen specimens from Gabon and Mozambique (though it seems unlikely that these would belong to a single species) and mentioning possible records from Tanzania. The genus Lanistes in Latin is masculine.

\section{superba Marshall, 1926}

FIGURE $1 \mathrm{~K}$

Ampullaria superba Marshall, 1926:3, pl. 1, fig. 9.

Current taxonomic status: Pomacea superba (Marshall, 1926); valid species (Cowie and Thiengo, 2003:75).

Type Material: Holotype USNM 362863, by original designation.

Type Locality: "Cienaga Totuma, Department of Atlantico, United States of Columbia" [Colombia].

Remarks: The "type" was figured and its USNM catalogue number and dimensions were given by Marshall (1926:4, pl. 1, fig. 9). The shell has the catalogue number and "type" written on the inside of its aperture. The original handwritten ledger indicates that it is the figured type, and the pattern of banding on the shell matches that in the illustration precisely. 


\section{tubaeformis Lea, 1856}

FIGURE 1L

Ampullaria tubœformis Lea, 1856:110.

Current taxonomic status: Incertae sedis in Ampullariidae; valid species (Cowie, 2015:56).

Type Material: Holotype USNM 106329, by monotypy.

Type Locality: Unknown.

Remarks: The original publication neither stated nor implied that the description was based on a single specimen. However, Lea (1866:114) subsequently indicated that it was indeed based on only a "single specimen" and USNM 106329 (labeled "holotype"), based on the banding pattern and the clear repair scar, is the specimen illustrated by Lea (1866: pl. 22, fig. 3); it bears the corresponding figure number inked on the body whorl. We accept this specimen as the holotype by monotypy (Code, Article 73.1.2). Although Lea (1856:110) gave no locality, he subsequently (Lea, 1866:114) said that the specimen "came with many other shells from India," and notes associated with the specimen and the original accession ledger (as "India?") also suggest this to be the case. However, the original ledger entry was crossed out and replaced with "Brazil" by J. P. E. Morrison and dated September 1955; a note with the specimen written by Morrison at the same time indicates, "probably from Rio di [sic] Janeiro or Brazil near Bahia." The location also has been suggested as "Siam" (Gaudion 1880:41). The shell appears more like that of a species of Pomacea (New World) than of Pila (Old World), but its correct generic placement and possible synonymy require further research. Not listed by Sowerby (1909:358, 1910:61, 1916:73) or by Cowie and Thiengo (2003).

\section{turbinis Lea, 1856}

\section{FIGURE 1M}

Ampullaria turbinis Lea, 1856:110.

Current taxonomic status: Synonym of Pila ampullacea (Linnaeus, 1758)

(Habe, 1964:49 [as “ampullaria"], Brandt, 1974:49; Ng et al., 2014:32;

Cowie, 2015:50).
Type Material: Lectotype USNM 106341, here designated; paralectotypes USNM 1270744 (formerly 106341X; 2 specimens).

Type Locality: "Siam" [Thailand].

Remarks: No holotype was designated, although USNM 106341 was labeled "holotype," and the description was based on three specimens (one adult, two young), according to the later description of Lea (1866:114). The shell in USNM 106341 is the shell illustrated by Lea (1866: pl. 22, fig. 2), based both on the banding pattern and the very clear repair scars or growth arrests, especially that at the start of the body whorl; it bears the corresponding figure number inked on the body whorl. We here designate this shell as the lectotype to stabilize the name. The paralectotypes (USNM 1270744, formerly 106341X), which are indeed smaller than the lectotype, were considered not conspecific with the lectotype, according to a note associated with the lot by J. P. E. Morrison, but this issue requires further research as the paralectotypes could simply be young individuals of the same species, as stated by Lea $(1866: 14)$.

\section{zeteki Morrison, 1946}

FIGURE 1N

Pomacea zeteki Morrison, 1946:8, pl. 1, fig. 3.

Current taxonomic status: Pomacea zeteki Morrison, 1946; valid species (Cowie and Thiengo, 2003:77).

Type Material: Holotype USNM 542137, by original designation; paratypes USNM 542138 (36 specimens).

Type Locality: “Chagres River near Gatuncilla, Republic of Panamá.”

Remarks: Additional material, listed as paratypes by Cowie and Thiengo (2003:77) and Cowie (2015:65), is present in various other museum collections. 


\section{Material Previously Considered as Types}

\section{zischkai Blume and Pain, 1952}

Pomacea zischkai Blume and Pain, 1952:267, pl. 7.

Current taxonomic status: Pomacea zischkai Blume and Pain, 1952; valid species (Cowie and Thiengo, 2003:77).

Type Material: None.

Type Locality: "Chapara Region, at 400 m. Bolivia tropica."

Remarks: The holotype, designated by Blume and Pain (1952:268), was reported by them as in Blume's collection; it is now in the ZSM (Cowie and Thiengo, 2003:77). Blume and Pain (1952:268) also listed five paratypes, one in Pain's collection (now in NMW) and four in the FMNH (Cowie and Thiengo, 2003:77). Blume and Pain (1952:268) noted that "the whole series examined" (they did not say "type" series) included "some 340 examples." Many of these were curated or cited as paratypes and noted as present in the ZSM and other museums by Cowie and Thiengo (2003:77) and as possible paratypes by Cowie (2015:65). However, all this additional material (presumably including those in USNM 667036, 2 specimens) was mentioned separately by Blume and Pain (1952:268) from their explicit designation of the holotype and five paratypes in their table, thereby expressly excluding them from the type series (Code, Article 72.4.6). 



\section{References}

Specific dates of publication and the sources from which they have been obtained can mostly be found in Cowie and Thiengo (2003) and Cowie (2015).

Alderson, E. G. 1925. Studies in Ampullaria. Cambridge, UK: Heffer.

Baker, H. B. 1930. The Mollusca Collected by the University of Michigan-Williamson Expedition in Venezuela. Part VI. Occasional Papers of the Museum of Zoology, University of Michigan, 210:1-95.

- 1964. Type Land Snails in the Academy of Natural Sciences of Philadelphia. Part III. Limnophile and Thalassophile Pulmonata. Part IV. Land and Fresh-Water Prosobranchia. Proceedings of the Academy of Natural Sciences of Philadelphia, 116:149-193.

Bennett, E. 1831. A Catalogue of the Organic Remains of the County of Wilts. Warminster, UK: [no publisher] Printed by J. L. Vardy.

Bequaert, J. C., and W. J. Clench. 1937. Forbesopomus, a New Genus in the Family Pilidae (Ampullariidae), from the Philippine Islands. Proceedings of the New England Zoölogical Club, 16:53-56, pl. 2.

Blume, W., and T. Pain. 1952. A New Species of Pomacea from Bolivia. Journal of Conchology, 23:267-268, pl. 7. Bouchet, P., and J.-P. Rocroi. 2005. Classification and Nomenclator of Gastropod Families. Malacologia, 47:1-397.

Brandt, R. A. M. 1974. The Non-Marine Mollusca of Thailand. Archiv für Molluskenkunde, 105:1-423, pls. 1-30

Cazzaniga, N. J. 2002. Old Species and New Concepts in the Taxonomy of Pomacea (Gastropoda: Ampullariidae). Biocell, 26:71-81.

Clench, W. J., and R. D. Turner. 1956. Freshwater Mollusks of Alabama, Georgia, and Florida from the Escambia to the Suwannee River. Bulletin of the Florida State Museum, Biological Sciences, 1:99-239.

Colgan, D. J., W. F. Ponder, E. Beacham, and J. Macaranas. 2007. Molecular Phylogenetics of Caenogastropoda (Gastropoda: Mollusca). Molecular Phylogenetics and Evolution, 42:717-737. doi:10.1016/j.ympev.2006.10.009.

Cowie, R. H. 1997. Pila Röding, 1798 and Pomacea Perry, 1810 (Mollusca, Gastropoda): Proposed Placement on the Official List, and Ampullariidae Gray, 1824: Proposed Confirmation as the Nomenclaturally Valid Synonym of Pilidae Preston, 1915. Bulletin of Zoological Nomenclature, 54:83-88.

- 2015. The Recent Apple Snails of Africa and Asia (Mollusca: Gastropoda: Ampullariidae: Afropomus, Forbesopomus, Lanistes, Pila, Saulea): A Nomenclatural and Type Catalogue. The Apple Snails of the Americas: Addenda and Corrigenda. Zootaxa, 3940:1-92. doi:10.11646/zootaxa.3940.1.1.

Cowie, R. H., N. J. Cazzaniga, and M. Glaubrecht. 2004. The South American Mollusca of Johann Baptist Ritter von Spix and Their Publication by Johann Andreas Wagner. The Nautilus, 118:71-87.

Cowie, R. H., K. A. Hayes, and S. C. Thiengo. 2006. "What Are Apple Snails? Confused Taxonomy and Some Preliminary Resolution.” In Global Advances in Ecology and Management of Golden Apple Snails, ed. R. C. Joshi and L. S. Sebastian, pp. 3-23. Muñoz, Nueva Ecija: Philippine Rice Research Institute.

Cowie, R. H., and V. Héros. 2012. Annotated Catalogue of the Types of Ampullariidae (Mollusca: Gastropoda in the Muséum national d'Histoire naturelle, Paris, with Lectotype Designations. Zoosystema, 34:793-824. doi:10.5252/z2012n4a8.

Cowie, R. H., and S. C. Thiengo. 2003. The Apple Snails of the Americas (Mollusca: Gastropoda: Ampullariidae: Asolene, Felipponea, Marisa, Pomacea, Pomella): A Nomenclatural and Type Catalog. Malacologia, 45:41-100.

Dall, W. H. 1898. Description of a New Ampullaria from Florida. The Nautilus, 12:75-76.

W. H. 1919. A New Form of Ampullaria. The Nautilus, 33:10-11.

W. H. 1921. Two New South American Shells. The Nautilus, 34:132-133.

D’Orbigny, A. [D.] 1838. Voyage dans l'Amérique Méridionale (le Brésil, la république orientale de l'Uruguay, la république Argentine, la Patagonie, la république du Chili, la république de Bolivia, la république du 
Pérou), exécuté pendant les années 1826, 1827, 1828, 1829, 1839, 1831, 1832 et 1833. Tome cinquième. 3.e partie: Mollusques. Paris: P. Bertrand; Strasbourg: V.e Levrault, 1835-1847.

_ 1842. "Mollusques. Tome second." In Histoire physique, politique et naturelle de l'ile de Cuba, ed. R. de la Sagra, pp. i-iv, 1-380, 28 pls. Paris: Arthus Bertrand, [1842-]1853.

Douvillé, H. 1904. Mission scientifique en Perse par J. de Morgan. Tome troisième. Études géologiques. Paléontologie. Deuxième partie. Mollusques fossiles. Paris: Ernest Leroux.

Fechter, R. 1983. Liste des Typenmaterials der von J. B. v. Spix in Brasilien gesammelten Gastropoda. Spixiana, supplement 9:221-223.

Gaudion, H. 1880. Liste alphabétique des espèces du genre Ampullaria de Lamarck. Bulletin de la Société d'Étude des Sciences naturelles de Béziers, 4(1879):20-43.

Gould, [A. A.] 1848. [No title; descriptions of shells from the collection of the exploring expedition.] Proceedings of the Boston Society of Natural History, 3:73-75.

- 1850. [No title; a number of new species of shells from Africa, recently presented by Dr. Perkins]. Proceedings of the Boston Society of Natural History, 3(1849):193-197.

- 1852. United States Exploring Expedition. Vol. 12. Mollusca \& Shells. Boston: Gould \& Lincoln, xvi + 510 pp., atlas.

Gray, J. E. 1824. Zoological Notices. The Philosophical Magazine and Journal, 63:274-277. doi:10.1080/14786442408644507.

- 1847. A List of the Genera of Recent Mollusca, Their Synonyma and Types. Proceedings of the Zoological Society of London, 15:129-219.

- 1868. Description of Saulea, a New Genus of Ampullariadæ [sic] from Sierra Leone. Proceedings of the Zoological Society of London, 1867:1000-1001.

Habe, T. 1964. Freshwater Molluscan Fauna of Thailand. Nature and Life in Southeast Asia, 3:45-66, pls. 1-2.

Hayes, K. A., R. L. Burks, A. Castro-Vazquez, P. C. Darby, H. Heras, P. R. Martín, J.-W. Qiu, S. C. Thiengo, I. A. Vega, T. Wada, Y. Yusa, S. Burela, M. P. Cadierno, J. A. Cueto, F. A. Dellagnola, M. S. Dreon, M. V. Frassa, M. Giraud-Billoud, M. S. Godoy, S. Ituarte, E. Koch, K. Matsukura, M. Y. Pasquevich, C. Rodriguez, L. Saveanu, M. E. Seuffert, E. E. Strong, J. Sun, N. E. Tamburi, M. J. Tiecher, R. L. Turner, P. L. Valentine-Darby, and R. H. Cowie. 2015. Insights from an Integrated View of the Biology of Apple Snails (Caenogastropoda: Ampullariidae). Malacologia, 58:245-302. doi:10.4002/040.058.0209.

Hayes, K. A., R. H. Cowie, and S. C. Thiengo. 2009. A Global Phylogeny of Apple Snails: Gondwanan Origin, Generic Relationships and the Influence of Outgroup Choice (Caenogastropoda: Ampullariidae). Biological Journal of the Linnean Society, 98:61-76. doi:10.1111/j.1095-8312.2009.01246.x.

Hayes, K. A., R. H. Cowie, S. C. Thiengo, and E. E. Strong. 2012. Comparing Apples with Apples: Clarifying the Identities of Two Highly Invasive Neotropical Ampullariidae (Caenogastropoda). Zoological Journal of the Linnean Society, 166:723-753. doi:10.1111/j.1096-3642.2012.00867.x.

Hylton Scott, M. I. 1958. Estudio morfologico y taxonomico de los ampullaridos de la Republica Argentina. Revista del Museo Argentino de Ciencias Naturales "Bernardino Rivadavia" e Instituto Nacional de Investigacion de las Ciencias Naturales. Ciencias Zoológicas, 3:[2 pp.+]233-333, 23 pls.

ICZN (International Commission on Zoological Nomenclature). 1999a. Opinion 1913. Pila Röding, 1798 and Pomacea Perry, 1810 (Mollusca, Gastropoda): Placed on the Official List, and Ampullariidae Gray, 1824: Confirmed as the Nomenclaturally Valid Synonym of Pilidae Preston, 1915. Bulletin of Zoological Nomenclature, 56:74-76.

- 1999b. International Code of Zoological Nomenclature, 4th ed. London: International Trust for Zoological Nomenclature.

Johnson, R. I. 1964. The Recent Mollusca of Augustus Addison Gould. Illustrations of the Types Described by Gould with a Bibliography and Catalog of His Species. United States National Museum Bulletin, 239: i-v, 1-182, pls. 1-45. doi:10.5479/si.03629236.239

Jørgensen, A., T. K. Kristensen, and H. Madsen. 2008. A Molecular Phylogeny of Apple Snails (Gastropoda, Caenogastropoda, Ampullariidae) with an Emphasis on African Species. Zoologica Scripta, 37:245-252. doi:10.1111/ j.1463-6409.2007.00322.x.

Köhler, F., and M. Glaubrecht. 2006. The Types of Ampullariidae Gray, 1824 (Mollusca, Gastropoda) in the Malacological Collection of the Natural History Museum, Berlin: An Annotated Catalogue with Lectotype Designations. Mitteilungen aus dem Museum für Naturkunde Berlin, Zoologische Reihe, 82:198-215. doi:10.1002/mmnz.200600006.

Lamarck, J. B. P. A. de M. de. 1799. Prodrome d'une nouvelle classification des coquilles, comprenant une rédaction appropriée des caractères génériques, et l'établissement d'un grand nombre de genres nouveaux. Mémoires de la Société d'Histoire Naturelle de Paris, 1:63-91.

partie. Paris: L'auteur.

Lea, I. 1838. Description of New Freshwater and Land Shells. Transactions of the American Philosophical Society, 6:1-111, pls. 1-30.

- 1856. Description of Thirteen New Species of Exotic Peristomata. Proceedings of the Academy of Natural Sciences of Philadelphia, 8:109-111.

- 1866. New Unionidae, Melanidae [sic], etc., chiefly of the United States. Journal of the Academy of Natural Sciences of Philadelphia, (new series) 6:113-187, pls. 22-24.

Linnaeus, C. 1758. Systema naturce per regna tria naturce, secundum classes, or dines, genera, species, cum caracteribus, differentiis, synonymis, locis. Tomus I. Editio decima, reformata. Holmiae [Stockholm]: Impensis Direct. Laurentii Salvii. doi:10.5962/bhl.title.542.

Marshall, W. B. 1926. New Land and Fresh-Water Mollusks from Central and South America. Proceedings of the United States National Museum, 69:1-12, pls. 1-3. doi:10.5479/si.00963801.69-2638.1.

1930. New Land and Fresh-Water Mollusks from South America. Proceedings of the United States National Museum, 77:1-7, pls. 1, 2.

McArthur, A. G., and M. G. Harasewych. 2003. "Molecular Systematics of the Major Lineages of the Gastropoda.” In Molecular Systematics and Phylogeography of Mollusks, ed. C. Lydeard and D. R. Lindberg, pp. 140-160. Washington, D.C.: Smithsonian Institution.

Melvill, J. C., and R. Standen. 1907. Notes on a Collection of Terrestrial and Fluviatile Mollusca, Made in North-Eastern Rhodesia during 1905, by Mr. Sheffield A. Neave, M.A., B.Sc. Memoirs and Proceedings of the Manchester Literary and Philosophical Society, 51(2)(article 4):1-16, unnumbered pl.

Montfort, D. de. 1810. Conchyliologie systématique, et classification méthodique des coquilles; offrant leurs figures, leur arrangement générique, leurs descriptions caractéristiques, leurs noms; ainsi que leur synonymie en plusieurs langues. Ouvrage destiné à faciliter l'étude des coquilles, ainsi que leur disposition dans les cabinets d'histoire naturelle. Coquilles univalves, non cloisonnées. Tome second. Paris: F. Schoell.

Morrison, J. P. E. 1946. The Nonmarine Mollusks of San José Island, with Notes on Those of Pedro Gonzáles Island, Pearl Islands, Panamá. Smithsonian Miscellaneous Collections, 106:1-49, pls. 1-3.

Neave, S. A. 1907. A Journey to North-East Rhodesia during 1904 and 1905. Memoirs and Proceedings of the Manchester Literary and Philosophical Society, 51(2) (article 3):1-7, unnumbered $\mathrm{pl}$.

Ng, T. H., S. K. Tan, and M. E. Y. Low. 2014. Singapore Mollusca: 7. The Family Ampullariidae (Gastropoda: Caenogastropoda: Ampullarioidea). Nature in Singapore, 7:31-47.

Pain, T. 1946. On Pila canaliculata and Its Locality. Proceedings of the Malacological Society of London, 27:58-59.

- 1949. Three New Species of Pomacea from South America. Proceedings of the Malacological Society of London, 27(6):257-258, pl. 13.

. 1950. A New Species of Pomacea (Limnopomus) from Venezuela. Journal of Conchology, 23:109-111.

- 1956. On a Collection of Pomacea from Colombia, with Description of a New Subspecies. Journal of Conchology, 24:73-79.

-1957. Pomacea of the Sierra de Merida, Venezuela. Journal of Conchology, 24:175-176.

Perry, G. 1810. Arcana; or the Museum of Natural History. London: Stratford, 1810-1811.

Philippi, R. A. 1852. Centuria quinta testaceorum novorum. (Contin.) Zeitschrift für Malakozoologie, 9:20-29.

Pilsbry, H. A. 1899. A New Ampullaria. Proceedings of the Academy of Natural Sciences of Philadelphia, 51:365.

- 1927. Revision of the Ampullariidae of Jamaica and Cuba. Proceedings of the Academy of Natural Sciences of Philadelphia, 79:247-253, pls. 21-22.

- 1933. Zoological Results of the Matto Grosso Expedition to Brazil in 1931,-II. Mollusca. Proceedings of the Academy of Natural Sciences of Philadelphia, 85:67-76, pl. 2.

Pilsbry, H. A., and J. T. Bequaert. 1927. The Aquatic Mollusks of the Belgian Congo. With a Geographical and Ecological Account of Congo Malacology. Bulletin of the American Museum of Natural History, 53:69-602, pls. 10-77.

Pilsbry, H. A., and A. A. Olsson. 1953. A Colombian Pomacea of the Effusa Group. The Nautilus, 66:98-99, pl. 6, fig. 6.

Ponder, W. F., D. Colgan, J. Healy, A. Nützel, L. R. L. Simone, and E. E. Strong. 2008. "Caenogastropod Phylogeny." In Phylogeny and Evolution of the Mollusca, 
ed. W. F. Ponder and D. R. Lindberg, pp. 329-382. Berkeley: University of California Press. doi:10.1525/california/9780520250925.003.0013.

Ponder, W. F., and D. R. Lindberg. 1997. Towards a Phylogeny of Gastropod Molluscs: An Analysis using Morphological Characters. Zoological Journal of the Linnean Society, 119:83-265. doi:10.1111/j.1096-3642.1997.tb00137.x.

Preston, H. B. 1915. The Fauna of British India, including Ceylon and Burma. Mollusca. (Freshwater Gastropoda \& Pelecypoda). London: Taylor and Francis.

Rochebrune, A. T. de, and L. Germain. 1904. Mollusques recueillis par la mission du Bourg de Bozas. Mémoires de la Société Zoologique de France, 17:5-29, pls. 1, 2.

Röding, P. F. 1798. Museum Boltenianum. Pars Secunda. Hamburg: J. C. Trapp.

Say, T. 1829. Descriptions of Some New Terrestrial and Fluviatile Shells of North America. The Disseminator of Useful Knowledge, 2:259-261. doi:10.5962/ bhl.title. 8024

Simone, L. R. L. 2004. Comparative Morphology and Phylogeny of Representatives of the Superfamilies of Architaenioglossans and the Annulariidae (Mollusca, Caenogastropoda). Arquivos do Museu Nacional, Rio de Janeiro, 62:387-504.
Sowerby, G. B. 1909. Notes on the Family Ampullariidae, with List of Species, Varieties, and Synonyms, Also Descriptions of Four New Species. Proceedings of the Malacological Society of London, 8:345-362.

- 1910. Notes on the Family Ampullariidae. Proceedings of the Malacological Society of London, 9:56-64.

1916. Notes on the Family Ampullariidae. Proceedings of the Malacological Society of London, 12:65-73.

Strong, E. E. 2003 Refining Molluscan Characters: Morphology, Character Coding and a Phylogeny of the Caenogastropoda. Zoological Journal of the Linnean Society, 137:447-554. doi:10.1046/j.1096-3642.2003.00058.x.

Strong E. E., O. Gargominy, W. F. Ponder, and P. Bouchet. 2008. Global Diversity of Gastropods (Gastropoda; Mollusca) in Freshwater. Hydrobiologia, 595:149-166. doi:10.1007/s10750-007-9012-6.

Thiengo, S. C., C. E. Borda, and J. L. B. Araújo. 1993. On Pomacea canaliculata (Lamarck, 1822) (Mollusca; Pilidae: Ampullariidae). Memórias do Instituto Oswaldo Cruz, 88:67-71. doi:10.1590/S0074-02761993000100011. 



\section{SUMMARY OF REQUIREMENTS FOR SMITHSONIAN CONTRIBUTIONS SERIES}

For comprehensive guidelines and specifications, visit www.scholarlypress.si.edu or Open SI (http://opensi.si.edu).

ABSTRACTS must not exceed 300 words.

TEXT must be prepared in a recent version of Microsoft Word; use a Times font in 12 point for regular text; be double spaced; and have 1 " margins.

REQUIRED ELEMENTS are title page, abstract, table of contents, main text, and references.

FIGURES should be numbered sequentially $(1,2,3$, etc.) in the order called out; have components lettered consistently (in size, font, and style) and described in captions; include a scale bar or scale description, if appropriate; include any legends in or on the figure rather than in a caption. Figures must be original and submitted as individual TIF or EPS files.

FIGURE FILES must not be embedded in the main text. Resolution for art files must be at least 300 dpi for grayscale and color images, and at least $1200 \mathrm{dpi}$ for line art. Color images should be requested only if required.

TAXONOMIC KEYS in natural history papers should use the aligned-couplet form for zoology. If cross referencing is required between key and text, do not include page references within the key but number the keyed-out taxa, using the same numbers with their corresponding heads in the text.

SYNONYMY IN ZOOLOGY must use the short form (taxon, author, year:page), with full reference at the end of the paper under "References."

REFERENCES should be in alphabetical order, and in chronological order for same-author entries. Each reference should be cited at least once in main text. Complete bibliographic information must be included in all citations. Examples of the most common types of citations are provided on SISP's “Author Resources” page at www.scholarlypress.si.edu. 